\title{
PROFESSOR JOHN PREBBLE'S GUIDING HAND IN NEW ZEALAND'S ADVANCE (BINDING) RULINGS REGIME
}

\author{
Adrian Sawyer*
}

At first glance, one could be excused for concluding that New Zealand's advance (binding) rulings regime can be traced to a Government budget announcement in 1992. In reality, the early efforts of Professor John Prebble in the mid-1980s laid the groundwork that eventually resulted in a binding rulings regime commencing in 1995. John's contributions not only provided input from reviewing comparative jurisdictions, but also a draft code. Furthermore, post-regime, John was instrumental in endorsing the regime through his membership of the Committee of Experts on Tax Compliance (the Committee). Beyond this, further refinements to the regime (including more cost-efficient and accessible short process rulings) to a large degree reflect John's early observations. That is, businesses need certainty when making decisions that affect their tax obligations imposed by complex legislation and they should have access to a facility that can enhance that certainty.

\section{INTRODUCTION}

I was privileged to receive an invitation from Zoë Prebble at Victoria University of Wellington (VUW) to write this article as a contribution to a special issue of the Victoria University of Wellington Law Review to honour Professor John Prebble's contributions to legal jurisprudence and practice over the past 45 years. I am possibly taking the liberty to refer to John in the first person, although I have known John personally since commencing my academic career nearly 30 years ago in 1991 . Prior to this, I had read some of his work while studying as an undergraduate university student at the University of Canterbury. Not only did I find the rigour of John's scholarship to be impressive but, in my view, his attention to detail in academic legal writing is without peer. John's service to scholarship is also prevalent in his capacity as an editorial/advisory board member for academic journals, including the New Zealand Journal of Taxation Law and Policy (for which I am one of the editors).

* Professor of Taxation, UC Business School, University of Canterbury, Christchurch New Zealand. Email: adrian.sawyer@canterbury.ac.nz. This states the position with respect to binding (advance) rulings in New Zealand as at 30 June 2021. 
On the other hand, John's wit and dry humour as a dinner speaker is something to behold, which I have been privileged to experience at academic conferences.

If one were to read John's bio on the website of the Faculty of Law at VUW, it would come as no surprise that his main teaching and research interests are in income tax law, specialising in basic principles of receipts, expenditure, timing, international taxation and anti-avoidance rules. ${ }^{1}$ Major contributions include the taxation of property transactions, companies and their investors, and controlled foreign corporations. ${ }^{2}$ A number of scholars and students will have engaged in the subdiscipline that John has pioneered, Jurisprudential Perspectives of Taxation Law, which examines judicial reasoning in taxation cases from the perspective of legal philosophers. ${ }^{3}$

John's contributions over many decades also extend to advising several governments on matters of tax reform, including being a member of the Government's consultative committees on corporate taxation and international taxation in the 1980s, and the VUW Tax Working Group in 2009-2010. ${ }^{4}$ John also served on the Committee in 1998, an important role where John made a long-lasting

1 See "Professor John Prebble" Victoria University of Wellington <www.wgtn.ac.nz>. John is also editor of the VUW Legal Research Papers series which is an abstracting e-journal that contains scholarly papers published or to be published by the Faculty of Law at VUW. It also includes the collection of the scholarly work of VUW's distinguished legal fellows. This e-journal is hosted by the Social Science Research Network [SSRN]. As measured by the SSRN, John's work is downloaded more often than any other New Zealand legal scholar. Furthermore, he is currently the third-most downloaded scholar of taxation law after two leading American academics. This achievement is particularly noteworthy as taxation (from a legal perspective at least) is a jurisdiction-specific discipline. See further "Professor of Law appointed Queen's Counsel" (8 June 2016) Victoria University of Wellington <www.wgtn.ac.nz>.

2 John Prebble The Taxation of Companies and Corporate Investors (Butterworths, Wellington, 1984); John Prebble The Taxation of Property Transactions (Butterworths, Wellington, 1986); and John Prebble The Taxation of Controlled Foreign Corporations (Institute of Policy Studies, Victoria University Press, Wellington, 1987).

3 See for example John Prebble "Ectopia, Formalism, and Anti-Avoidance Rules in Income Tax Law" in Werner Krawietz, Neil MacCormick and Georg Henrik von Wright (eds) Prescriptive Formality and Normative Rationality in Modern Legal Systems: Festschrift for Robert S Summers (Duncker and Humblot, Berlin, 1994) at 367-383; and John Prebble "Ectopia, Tax Law, and International Taxation" [1997] British Tax Review at 383-403.

4 Consultative Committee on Full Imputation and International Tax Reform International Tax Reform Part 1: Report of the Consultative Committee (March 1998); Consultative Committee on Full Imputation and International Tax Reform Full Imputation: Report of the Consultative Committee (March 1988); Consultative Committee on Full Imputation and International Tax Reform International Tax Reform and Full Imputation Part 2: Report of the Consultative Committee (July 1988); and Consultative Committee on Full Imputation and International Tax Reform International Tax Reform and Full Imputation Part 2: Draft Legislation (July 1988). See also Victoria University of Wellington Tax Working Group A Tax System for New Zealand's Future (Centre for Accounting, Governance and Taxation Research, 2010). 
contribution (which I will discuss later in this article). ${ }^{5}$ John has a further interest in private international law and the law of elections. Further recognition of John's outstanding contributions was made in 2016 when he was appointed Queen's Counsel (QC) under the Royal Prerogative in recognition of his extraordinary contribution to the law. ${ }^{6}$

Given the scope of John's scholarship, this article by necessity focusses on his contributions to taxation and to a specific area within the discipline. One area not mentioned specifically in John's bio, but which appears prominently in his publications, is that of binding (advance) rulings. Before embarking on these contributions in the next section of the article, a brief comment is warranted on what I mean by binding (advance) rulings as a legislatively supported administrative feature. A useful working description of binding rulings (as the term is used in New Zealand) is provided by Inland Revenue in its guide on binding rulings: ${ }^{7}$

\begin{abstract}
A binding ruling is Inland Revenue's interpretation of how a tax law applies to a particular arrangement, person or item of property. This can be on any agreement, contract, plan or understanding (whether enforceable or not), including any steps and transactions that carry it into effect or it can be whether a person or item of property meets the requirements of the tax law.
\end{abstract}

Binding rulings can provide certainty on the tax position for a wide range of transactions, from complex financing transactions to land subdivisions. Anyone can apply for a binding ruling on a transaction, but there are some restrictions on our ability to provide a binding ruling, ...

If a binding ruling applies to a taxpayer and they follow it, Inland Revenue is bound by it (provided that the facts are exactly as described in the ruling, and that the stipulated conditions are satisfied). A taxpayer is not required to follow the approach in the ruling.

The legislative framework that is set out in the Tax Administration Act 1994 is more extensive and will be discussed further in the next section of this article. ${ }^{8}$ Thus, I hope that it is clear to readers at this point that a major focus of this article will be on John's contributions that led to establishing the legislative binding rulings regime that operates in New Zealand, along with some of its subsequent reviews.

5 Committee of Experts on Tax Compliance Tax Compliance: A Report to the Treasurer and Minister of Revenue by a Committee of Experts on Tax Compliance (19 December 1998).

6 Professor John Prebble is only the third tax academic to be granted silk (appointed Queen's Counsel) on the basis of his scholarly work after Professor Vern Krishna of Ottawa (1989) and Professor John Tiley of Cambridge (2009). See further "Professor of Law appointed Queen's counsel" (8 June 2016) <www.wgtn.ac.nz>.

7 Inland Revenue Binding rulings: How to get certainty on a tax position (IR715, February 2020) at 4 (emphasis added).

8 See specifically Part VA, ss 91A to 91J. 
The remainder of this article is set out as follows. Part II provides an overview of John's seminal work that was published in 1986 along with other related research leading to the establishment of the binding rulings regime in New Zealand. ${ }^{9}$ Without these contributions New Zealand may not have got the model legislative regime that it has now, or at a relatively early stage, compared to many other jurisdictions. I have again taken the liberty to intersperse the discussion of John's contributions with my own published contributions to the area of binding rulings, along with some analysis of the policy behind the regime. Part III will look at John's contributions since the binding rulings regime has been in place, in particular the period while he served on the Committee in the late 1990s. This discussion will be followed in Part IV by a review of the more recent refinements to, and extensions of, the binding rulings regime. Part $\mathrm{V}$ contains the concluding observations, including my reflection on how John might comment on the current state of binding rulings in New Zealand within the context of his earlier vision.

\section{MAJOR PIONEERING WORK CALLING FOR A FORMAL ADVANCE (BINDING) RULINGS REGIME IN NEW ZEALAND \\ A Advancing the Cause - Pioneering Work on Advance Rulings}

Why is there a need for binding advice from the Commissioner of Inland Revenue (the Commissioner) that taxpayers can rely on? It has been acknowledged by academics and practitioners alike for many years that tax law is one of the most complex areas of law. This is, as John has previously stated, because: ${ }^{10}$

Income tax law is different from law in general, and from tax laws that depend on transactions or on states of fact. Unlike other laws, income tax law does not relate directly to its subject matter, which is the facts and legal relationships of business activity. Income tax law ignores some facts and transactions and it recharacterises others. In other words, tax law is dislocated from its subject matter.

Thus, John's perspective is that tax law is dislocated from its subject matter and it depends on the concept of income which can be viewed as an artificial construct. Given this philosophical perspective, the task of reducing uncertainty in complex law is one of the greatest challenges facing the Commissioner and tax practitioners.

Before embarking on an in-depth review of John's contributions to the literature on binding rulings, it is worthwhile setting out his major publications in the mid-1980s and then an evaluation of binding rulings after the regime was fully in place with effect from 1 April 1995. John's major contributions include three publications completed before the regime commenced in 1995, one concurrently with the introduction of the regime and one early on in its period of operation:

9 John Prebble Advance Rulings on Tax Liability (Institute of Policy Studies, Victoria University Press, 1986).

10 John Prebble "Should Tax Legislation be Written from a Principles and Purpose Point of View or a Precise and Detailed Point of View?" (2001) 7 NZJTLP 235 at 235 (emphasis added). 
- John Prebble "Advance rulings procedures" (1985) 15 VUWLR 237;

- John Prebble Advance Rulings on Tax Liability (Institute of Policy Studies, Victoria University Press, 1986) at $1-197 ;^{11}$

- John Prebble "Canadian and Swedish Procedures for advance rulings in income tax cases" (1987) 4 Australian Tax Forum 217;

- John Prebble "Advance rulings: a proposed procedure" in M Gammie and A Shipwright (eds) Striking the Balance: Tax Administration, Enforcement and Compliance in the 1990s (Institute for Fiscal Studies, London, 1996) at 94-128; and John Prebble "Draft legislation to establish and advance rulings procedure" in M Gammie and A Shipwright (eds) Striking the Balance: Tax Administration, Enforcement and Compliance in the 1990s (Institute for Fiscal Studies, London, 1996) at 209-230;

- Ian Kuperus and John Prebble "Advance rulings" (1999) 74b Cahiers de Droit Fiscal International 535 .

The second publication above is by far the most important, being the seminal work that evaluates the Swedish, Canadian and United States of America advance rulings regimes from which the basis for a binding (advance) rulings system was proposed for New Zealand (with a draft legislative code). The abstract to this work on the Social Science Research Network (SSRN) website states: ${ }^{12}$

As commercial transactions and tax law have both become more complex, tax practitioners have called for the establishment of procedures whereby taxpayers can find out in advance the official opinion of the revenue authorities as to the tax implications of their proposed transactions. If formally issued, such opinions should operate as rulings that are binding on the Crown even if they are later discovered to be wrong in law or if the Revenue changes its opinion. This book was written primarily for the purpose of describing and making recommendations for an advance rulings procedure that might be appropriate for New Zealand. It is also a comparative study of advance rulings procedures used in other countries, and in particular, the United States of America, Canada, and Sweden. It contains a draft statutory code. New Zealand adopted a 'Determination' system for rulings in respect of loans and other financial arrangements and as a general 'Rulings' system for rulings on other areas of the law. Both systems follow the principles that the author advocates.

11 A similar work in the United Kingdom context was published by D Sandler A Request for Rulings (Institute of Taxation and Institute for Fiscal Studies, 1994). For a comprehensive review of rulings internationally, including a proposal for a European tax rulings system, see C Romano Advance Tax Rulings and Principles of Law: Towards a European Tax Rulings System (Doctoral Series vol 4, IBFD, 2002).

12 See Prebble Advance Rulings on Tax Liability, above n 9, at abstract (emphasis added). 
As this abstract indicates, John's seminal work makes three major contributions, namely it:

- $\quad$ provides a comparative study of three jurisdictions that operate an advance (binding) rulings system, albeit in very different ways; ${ }^{13}$

- makes recommendations for a binding rulings regime that would be appropriate for New Zealand conditions, including raising a number of crucial policy issues requiring determination; and

- $\quad$ provides draft statutory provisions (to be inserted into the Inland Revenue Department Act 1974 , as was in force at that time).

Specifically, in this seminal work, John sets out the reasons for advance rulings, the New Zealand experience (as at the mid-1980s), the rulings procedures in four countries (Canada, New Zealand, Sweden and the United States of America) and the key features of what a best practice rulings system should contain. ${ }^{14}$ The calibre of this work is aptly stated in the preface to the work where Dr S Lojkine (Chair of the Institute of Policy Studies) observes: ${ }^{15}$

It may seem a bold step to be advocating tax reform in an area not presently contemplated by a government intent on reshaping taxation law in a number of areas which have been selected on the basis of urgency of need for reform. Bold it certainly is, but it also a logical outcome of recognising that the whole objective of advance rulings procedures is to increase the certainty of tax administration between revenue and taxpayer. Such certainty is more than ever desirable in times when the taxation system of our country is undergoing continual and comprehensive change. [...]

It is hoped that publication of Advance Rulings on Tax Liability will stimulate discussion of the issues involved, not just on a theoretical basis, but will a view to a practical conclusion being reached as to whether or not reform in this area would be beneficial, and if so, how it should be implemented. The issues have been fully and most aptly exposed by Dr Prebble, and provide a broad and deep foundation for such discussion.

Also in his seminal work, John sets out reasons why binding (advance) rulings are needed, including recognising that the complexity of the business environment is increasing and taxpayers are desiring greater certainty over their tax liability. ${ }^{16}$ Two years prior to the book being published, the New Zealand economy had commenced its most significant restructuring, including freeing up of

13 Interestingly, as will be discussed later, the policy analysis that underpinned New Zealand's regime compared Australia, Canada and the United States, and not Sweden. This may in part be due to Sweden's rather unique approach of having a separate body to the revenue authority that issues advance rulings. The work also sets out in an appendix details of the advance rulings' directorates of Revenue Canada (as it was then known).

14 Prebble Advance Rulings on Tax Liability, above $\mathrm{n} 9$.

15 At 14-15 (emphasis added, not bold).

16 Chapter 1. 
regulations and major tax reform. Concurrent with this change, tax practitioners and commentators were firmly of the view that a binding (advance) rulings regime was needed.

Certainty is sought to reduce the likelihood of expensive disputes between taxpayers and the revenue authority (Inland Revenue). Taxpayers' concern about the lack of certainty was growing substantially in the early 1980s, highlighted by the Commissioner's statement on the various forms of advice (s)he provided, as set out in Public Information Bulletin 177 in June 1982. The key features of the rulings and advice system at that time was that: ${ }^{17}$

- $\quad$ The Inland Revenue Department does not consider itself obliged to issue rulings, though it endeavours to do so. One type of case where the Department may not give a ruling is where there is some doubt about the applicable law;

- There is no appeal from unfavourable rulings. The taxpayer may carry on if they wish and challenge the view of the department when a return has been furnished and an assessment issued;

- The Department emphasises that its rulings are expressions of opinion and are not binding. Of course, the ruling may be revoked if it is subsequently discovered that the facts are not as stated by the taxpayer. However, changes in the law or its interpretation will also cause the department to correct its ruling;

- Application for a ruling is by letter setting out the facts of the case together with drafts of relevant documents; and

- The Department will not give rulings on proposals which involve or could involve tax avoidance, hypothetical situations, a series of alternatives to the same transaction or proposals where the names of the taxpayers are not disclosed.

The most crucial point is that these rulings were considered to be opinions and not binding on Inland Revenue, meaning that the Commissioner could change his or her interpretation of a law at a future time. Furthermore, issuing such forms of guidance for taxpayers was at the discretion of the Commissioner. John's central argument, with which I concur, is that tax liability is so important for many taxpayers that it ought to be possible to determine in advance what this liability will be. The system prior to the arrival of the binding rulings regime was failing in this regard.

In order to move forward, an argument needed to be developed to support a proposal for some form of binding rulings (that is, rulings that would bind the Commissioner to his or her interpretation of the law as set out in the ruling, provided all necessary requirements are met). Logically, it is important to avoid "reinventing the wheel" if there are relevant regimes in operation elsewhere that could be explored and potentially adapted for New Zealand conditions. In this regard, the three regimes John reviewed in his seminal work provide contrasting examples of blueprints for New Zealand (for example, a separate body to issue rulings as applies in Sweden, fees for service as applied

17 Inland Revenue "Incomplete or proposed transactions - advance rulings and interpretations" (1982) Public Information Bulletin No 117 at 12 (emphasis added). 
in Canada and Sweden at that time, conferences during the process, revocation, appeals, publication and the like). ${ }^{18}$ From these potential precedents, a model for New Zealand was proposed which would potentially fit the New Zealand environment, including a number of policy issues that would need to be worked through.

Crucial to an effective regime is a legislative scheme that gives effect to the binding nature of the rulings that are issued. John's work provides the basis for a legislative code that could be refined by the Parliamentary Counsel Office/Inland Revenue drafter into a Bill amending the relevant New Zealand tax legislation. ${ }^{19}$

The first, third and fourth contributions ${ }^{20}$ support the contributions of John's seminal book. ${ }^{21}$ Specifically the Victoria University of Wellington Law Review article makes the case for a binding rulings regime for New Zealand, including a discussion of the key issues to be resolved. The Australian Tax Forum paper provides extensive material from a colloquium held in London on 11 September 1985, where aspects of the Canadian and Swedish advance rulings regimes were explored.

The 2016 book, Striking the Balance: Tax Administration, Enforcement and Compliance in the 1990s, contains a chapter and appendix prepared by John in 1993 (just a little prior to the proposed New Zealand regime but after the Government had announced that it was investigating developing a binding ruling regime). Of particular interest is the appendix to this work that provides draft legislation that could be adapted for New Zealand, including explanatory notes. Notably, there is a high degree of "overlap" between this proposal and what was eventually enacted in New Zealand. Collectively, through all of these publications, John was seeking to increase the level of discussion on advance rulings and ensure the need for such a regime was placed clearly in front of officials and the Government.

18 Prebble Advance Rulings on Tax Liability, above $\mathrm{n} 9$.

19 At that time this included the Income Tax Act 1976 and the Inland Revenue Department Act 1974.

20 John Prebble "Advance rulings procedures" (1985) 15 VUWLR 237; John Prebble "Canadian and Swedish Procedures for advance rulings in income tax cases" (1987) 4 Australian Tax Forum 217; John Prebble "Advance rulings: a proposed procedure" in M Gammie and A Shipwright (eds) Striking the Balance: Tax Administration, Enforcement and Compliance in the 1990s (Institute for Fiscal Studies, London, 1996) at 94128; and John Prebble "Draft legislation to establish and advance rulings procedure" in M Gammie and A Shipwright (eds) Striking the Balance: Tax Administration, Enforcement and Compliance in the 1990s (Institute for Fiscal Studies, London, 1996) at 209-230. See also John Prebble Practical Problems from Publication of the Commissioner's Interpretation Guidelines (Working Paper No 8, Centre for Accounting, Governance and Taxation Research, Victoria University of Wellington 2002).

21 Prebble Advance Rulings on Tax Liability, above n 9. 


\section{B Development and Implementation of New Zealand's Binding (Advance) Rulings Regime}

With this background, it is now pertinent to review briefly how New Zealand got its binding rulings regime. Following from the release of John's seminal work, it took a number of years for proponents of a binding rulings regime to convince the Government of the need to develop policy in this area and meet the challenge to overcome Inland Revenue's reluctance to accept the need for a binding form of advance ruling. Inland Revenue was largely satisfied with the process outlined in PIB 117 as it suited the Commissioner and the department.

Nevertheless, concern was widespread over Inland Revenue changing the position it had taken when providing non-binding rulings/advice (usually the change was for a justifiable reason or Inland Revenue had changed its preferred view) along with the lack of legal action to enforce the interpretation contained in non-binding rulings. In effect these rulings provided nothing more than an indicative view of the Commissioner's interpretation and application of the law which should not be relied upon by taxpayers for the duration of an arrangement.

Attempts by taxpayers to apply estoppel and specific performance standards against the Commissioner also failed. ${ }^{22}$ As Alston observes, the Commissioner is under a statutory duty to collect the highest revenue that is practicable over time. ${ }^{23} \mathrm{He} /$ she cannot exercise a discretion to reduce a taxpayer's liability unless there is specific statutory authority to do so. Consequently, "... estoppel cannot be raised against the Commissioner and an intra vires exercise of the assessment function is not amenable to judicial review." 24

Overall, the environment was untenable in a modern business environment and change was needed. John's seminal work was the most significant publicly available source available to the Government and officials to form the basis for such a momentous change. The importance of a formalised binding rulings regime is that the Commissioner can only be bound by a binding ruling he/she has issued where this is authorised by legislation in order that the principle established in Lemmington Holdings is not infringed. ${ }^{25}$

22 See for example Commissioner of Inland Revenue v Lemmington Holdings [1982] 1 NZLR 517, (1982) 5 NZTC 61 [Lemmington Holdings] at 268.

23 See Tax Administration Act 1994, s 6A.

24 A Alston "Taxpayers' Rights in New Zealand" (1997) 7(1) Revenue Law Journal 211 at 212. See also C Rider "Estoppel of the revenue: A review of recent developments" (1994) 23(3) Australian Tax Review 135. For a more recent discussion see J Vaughan "Statements issued by the Commissioner of Inland Revenue - With recent legislative changes what is their legal status?"(MBus Dissertation, Auckland University of Technology, 2008).

25 Lemmington Holdings, above n 22. 
As noted earlier, rulings issued before this time were not binding on the Commissioner. Significant progress towards changing this situation was made when the Government released a discussion document in June 1994 outlining its proposal for a binding rulings regime, including draft legislation. ${ }^{26}$ This followed an announcement in the 1992 Budget of the Government's intention to introduce a system for issuing binding rulings on tax matters. ${ }^{27}$ This 1992 Budget announcement gave effect to an earlier recommendation from the Tax Simplification Consultative Committee several years earlier under the chairmanship of John Waugh. ${ }^{28}$ The Tax Simplification Consultative Committee recommended (as a high priority):

- work be undertaken to change the law to make binding on the Inland Revenue its publicly released general rulings on tax matters; and

- a practical system of taxpayer-specific binding rulings be developed.

The principal point of comparison in the discussion document was the Australian regime, not that of Canada, Sweden or the United States of America, as John used in his seminal work. ${ }^{29}$ In some respects, the Government's choice of comparison led to a much narrower range of policy options than those that could have been explored. Nevertheless, while the New Zealand regime benefited from the prior Australian experience, including avoiding some of its pitfalls, it left out several key features, such as providing for a system of appeals/challenges to rulings.

The discussion document identified two types of certainty that would be addressed, namely "transaction certainty" and "compliance certainty". It defined these terms as follows: ${ }^{30}$

Certainty about the tax implications of proposed transactions leads to increased efficiency since taxpayers know the tax cost before deciding whether or not to undertake a transaction. The term 'transaction certainty' describes the form of business certainty that arises when taxpayers know in advance the tax treatment of their proposed transactions.

The second type of certainty mentioned in the 1992 Budget can be termed 'compliance certainty'. A binding ruling reassures taxpayers that the matter will not be subject to a higher tax liability, provided the terms of the transaction do not change. The risk of incurring a penalty for non-compliance is also effectively eliminated.

26 B Birch and W Creech Binding Rulings on Taxation: A discussion document on the proposed regime (June 1994).

27 R Richardson Budget 1992 (2 July 1992).

28 J Waugh Tax Simplification: Final Report of the Consultative Committee (July 1990) at chapter 3.

29 Prebble Advance Rulings on Tax Liability, above $\mathrm{n} 9$.

30 Birch and Creech, above n 26, at [2.6]-[2.7] (emphasis added). 
Draft legislation was released for public comment and submissions were received. As a result of the feedback, officials recommended some refinements be made. ${ }^{31}$ Part 5A of the Tax Administration Act 1994 sets out the binding rulings regime, including subsequent amendments. The first remedial review occurred in 1999, with the most recent significant amendment occurring in 2019. Alongside the regime, there is a facility for issuing determinations in Part 5 of the Tax Administration Act 1994, which includes determinations in relation to financial arrangements, transfer pricing (by way of an advance pricing agreement or APA) and special depreciation rates.

The purpose of the binding rulings regime is provided in s 91A of the Tax Administration Act 1994 and provides (emphasis added):

The purpose of this Part is to -

(a) provide taxpayers with certainty about the way the Commissioner will apply taxation laws; and

(b) help them to meet their obligations under those laws, -

by enabling the Commissioner to issue rulings that will bind the Commissioner on the application of those

laws. The Part also recognises the importance of collecting the taxes imposed by Parliament and the need

for full and accurate disclosure by taxpayers who seek to obtain binding rulings.

In order to assess the extent to which John's vision is reflected in the New Zealand binding (advance) rulings system, an overview of the regime needs to be set out. The rulings system contains a set of common provisions that allow the Commissioner to make rulings under a range of statutes, including statutes covering income tax, goods and service tax (GST) and fringe benefits tax (FBT). ${ }^{32}$ Section 91C of the Tax Administration Act 1994 was extensively modified with effect from 1 April 2019 to provide for short process rulings. ${ }^{33}$ In addition to the common provisions, there are also

31 For further discussion see for example the following publications by the author: A Sawyer "Binding Tax Rulings: The New Zealand Experience" (1997) 26(1) Australian Tax Review 11; A Sawyer "What are the Lessons for Australia from New Zealand's First Comprehensive Remedial Review of its Binding Rulings Regime?" (2000) 29(3) Australian Tax Review 133; AJ Sawyer An International Comparison of Binding Rulings Regimes, A Report for the Adjudication and Rulings Division of the Inland Revenue Department (November 2001); A Sawyer "Comparing New Zealand's Private Rulings System and its Features with a Selection of International Private Rulings Systems - What is There in Common?" (2002) 5(3) Journal of Australian Taxation 440; A Sawyer "Binding Rulings: A Comparative Perspective" in Andrew Lymer and John Hasseldine (eds) The International Taxation System (Kluwer, Amsterdam, 2002) at 291; and A Sawyer "Binding Rulings in New Zealand - An Overview and Review of the First Ten Years" (2006) 12(2) Canterbury Law Review 273 [updated as: A Sawyer "Binding Rulings in New Zealand - An Overview and Review of the First Ten Years" in Adrian Sawyer (ed) Taxation Issues in the Twenty First Century (Centre for Commercial and Corporate Law, Christchurch, 2006) at 195-213]. For a comprehensive theoretical and global analysis, see B Alarie and others "Advance Tax Rulings in Perspective: A Theoretical and Comparative Analysis" (2014) 20(4) New Zealand Journal of Taxation Law and Policy 362.

32 Tax Administration Act, s 91C(1).

33 There is further discussion on this issue in Part V of the article. 
specific provisions relating to the making of public rulings, ${ }^{34}$ private rulings, ${ }^{35}$ product rulings,${ }^{36}$ and status rulings. ${ }^{37}$ There is no provision for oral rulings under the binding rulings system in New Zealand.

A ruling binds the Commissioner if the ruling applies to a person and that person relies on the ruling by applying the taxation law(s) in the way stated in the ruling to their arrangement. ${ }^{38}$ As a consequence, a taxpayer who relies on a ruling is protected against additional tax, penalties or interest that would otherwise be payable under the law. A private ruling or product ruling is, however, only binding in relation to the specific arrangement(s) stated in the ruling (or, in the case of a public ruling, to any arrangement of the type indicated in the ruling). By following the interpretation in a ruling, this will usually reduce any shortfall penalty that may arise under pt 9 of the Tax Administration Act 1994. This is an important feature to enhance taxpayer certainty and reduce the risk of greater tax liabilities.

In the rare situation of conflicting rulings, a taxpayer may choose which ruling to follow, although it is likely that the Commissioner will not enable such conflicts to prevail for any significant length of time. If this situation is a result of a minor error, the error can be corrected, provided this does not affect the meaning of the ruling. ${ }^{39}$ Also, an applicant needs to be aware that the Commissioner will not issue a ruling if the applicant has outstanding debts from other ruling applications. ${ }^{40}$

Private rulings are not published (although the original discussion document indicated they should be with identifying information removed). ${ }^{41}$ Public rulings, product rulings and status rulings on product rulings are published (with a period of delay for product rulings and status rulings on product rulings). Private, product and status rulings are charged for on a full cost recovery basis at the rates prescribed in the Tax Administration (Binding Rulings) Regulations 1999 (updated in 2019). ${ }^{42}$ Rulings cannot be appealed by the taxpayer, rather a taxpayer applicant has a choice of whether to

34 Tax Administration Act, ss 91D-91DE

35 Sections 91E-91EJ.

36 Sections 91F-91FK.

37 Sections 91G-91GH.

38 Sections 91DB, 91EA and 91FA.

39 Section 91GI.

40 Section 91J.

41 Birch and Creech, above n 26, at 33-34.

42 Fees are currently $\$ 280$ plus GST on application and \$140 plus GST per hour. Short process ruling fees are lower. It is debatable whether these figures reflect "full cost recovery" as the concept would be understood by accountants. In addition to these fees, applicants will also need to pay the not insignificant fees (and associated costs) of their tax practitioner in preparing the ruling application and draft ruling. 
follow the ruling or not. A decision to not follow a ruling could have adverse consequences for a taxpayer, including possible exposure to shortfall penalties.

At a high level, the regime New Zealand adopted reflects a majority of John's recommendations, with the significant exception of publication of deidentified private rulings. John's focus was on private rulings (these being the most important for businesses) and did not encompass directly public rulings or the nuances of product rulings. The concept of status rulings did not become an issue until the tax law rewrite programme was underway with the desire to provide certainty over whether or not changes in legislative wording amounted to a change in the law (and how this would affect existing rulings). ${ }^{43}$ Unsurprisingly, the binding rulings legislation is more detailed than that drafted by John as part of his seminal work and his subsequent contributions.

In 1999, Professor John Prebble, along with Ian Kuperus, provided the New Zealand National Report on advance rulings to the International Fiscal Association's 1999 Congress. At this time, the New Zealand regime had been in operation for about four years. As national reporters, their evaluation of private and product rulings reflects a concern that remained at least until the recent 2019 amendments, namely that the regime is too costly for smaller businesses to utilise in order to increase certainty concerning their tax liabilities. Most users were reported as being reasonably satisfied with the operation of the regime. ${ }^{44}$

In my reflection on the first 10 years of operation of the binding rulings regime in 2006, I arrive at the following conclusion: ${ }^{45}$

In sum, while the first ten years of the New Zealand model reveal a model that has been successful in generating demand and delivering high quality outputs, the partial 'strangulation' of the process through resourcing constraints and a growing complexity of applications (as measured by the number of complex issues), suggests considerable room for streamlining of the process and further resourcing commitment from the Government.

As alluded to earlier, in modelling the New Zealand regime on the Australian regime (as it operated in 1995), there were a number of missed opportunities. This includes omitting to incorporate a facility for applicants to appeal or challenge to a ruling. That said, there is the opportunity through the consultation process for a taxpayer applicant to withdraw their application or subsequently to take a somewhat risky decision to not follow a binding ruling once it has been issued. Another missed

43 For a review of the tax rewrite programme by the author see for example AJ Sawyer "New Zealand's Tax Rewrite Program - In Pursuit of the (Elusive) Goal of Simplicity" (2007) 4 BTR 405; and AJ Sawyer "Rewriting Tax Legislation: Can Polishing Silver Really Turn It Into Gold?" (2013) 15(1) Journal of Australian Taxation 1.

44 Ian Kuperus and John Prebble "Advance rulings" (1999) 74b Cahiers de Droit Fiscal International 535 at 540.

45 Sawyer "Binding Rulings in New Zealand - An Overview and Review of the First Ten Years", above n 31, at 291 (emphasis added) 
opportunity was to enable some form of publication of private rulings. While I am also in favour of some form of sanitised private rulings being published, I do recognise that in a small jurisdiction like New Zealand this would be a difficult exercise in relation to some readily identifiable taxpayers. ${ }^{46}$ That said, publication would enhance the stock of "precedents" along with reduce the chance of an advantage to those applicants who have a tax practitioner with access to the content (including legal positions) in a number of private rulings secured for other clients. This situation could be interpreted as facilitating a form of "secret law" where particular views/interpretations of the Commissioner are known only to a select few.

New Zealand's "inventiveness" with respect to rulings is reflected in the creation of the status ruling, a type of ruling to the best of my knowledge that is unique to the New Zealand regime. Nevertheless, while a status ruling on a private ruling is not able to be published, there is no evidence of any published status rulings on existing product rulings. In this regard, it is difficult to argue that status rulings are a core feature of the New Zealand binding rulings regime.

The administrative and policy reviews of the rulings process have led to improvements, including the 2019 amendments which will be discussed shortly. In reflecting on the success of the regime from an operational perspective, the following data from Inland Revenue's 2019 Annual Report is instructive: 47

Table 1: Extract of rulings performance data

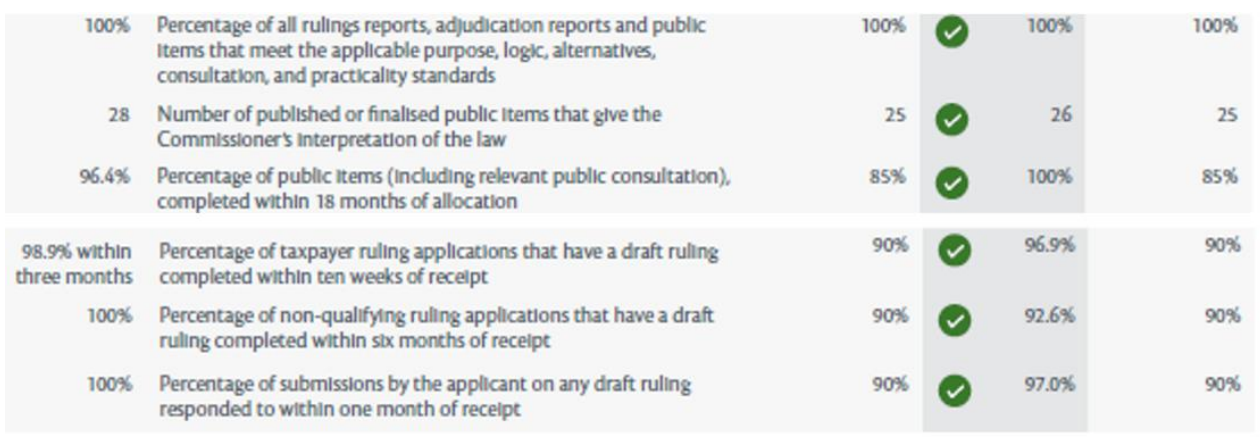

This data suggests that the regime has been performing well in recent years, in comparison to 10 to 15 years ago. That said, it is difficult to make comparisons. In the first 10 to 15 years, data was reported based on the number of applications and issues, not on the degree to which targets of

46 See Sawyer "Binding Tax Rulings: The New Zealand Experience", above n 31; and Sawyer "Binding Rulings in New Zealand - An Overview and Review of the First Ten Years", above n 31.

47 Inland Revenue Annual Report (2020) at 91-92. The columns with performance data represent: 2018-2019 Actual, 2019-2020 Target, 2019-2020 Actual and 2020-2021 Target. 
responses and issuing of rulings were met. ${ }^{48}$ Notwithstanding the resource constraints, Inland Revenue has sought to meet all quality standards and in the early years frequently exceeded its timeliness standards (including that of allocation to an analyst) with draft rulings usually finalised within a year of receipt of the application. Inland Revenue's centralised model (via the Taxpayer Rulings Unit, along with a period incorporating the Corporates Unit) and consultative approach is a positive feature, even though this slows down the process of analysing an application and issuing a ruling. The costs involved also preclude many smaller taxpayers from making applications. The absence of an expedited process also means in some cases that the taxpayer applicant cannot afford to wait for Inland Revenue to issue the final ruling before making a decision whether to proceed with an arrangement.

Before reflecting on the more recent reforms, this article will briefly review another of John's important contributions to the ongoing review of the binding rulings regime through his membership of the Committee.

\section{A REVIEW OF THE BINDING RULINGS REGIME - THE COMMITTEE OF EXPERTS ON TAX COMPLIANCE}

The Committee of Experts on Tax Compliance was set up mid-March 1998, issuing its final report in December $1998 .{ }^{49}$ Broadly, the Committee's terms of reference required it to consider and make recommendations on tax compliance costs and the robustness of the tax system against avoidance and evasion. Chapter 17 of the Committee's Report, Tax Compliance, addresses binding rulings and is located within Part 4 which focusses on "operational" matters. This chapter provides the Committee's opinion from its review of the binding rulings regime. An important observation is made that the (Taxpayer) Rulings Unit in Inland Revenue seeks to maintain the highest standard in its work through using staff of the highest calibre. Specifically, in relation to private rulings, the following evaluation statement is provided by the Committee with respect to the matter of whether such rulings should be published: ${ }^{50}$

17.18 The committee considered whether private rulings should be required to be published in an anonymous form. This step would have the merit of permitting public scrutiny of rulings and of allowing public access to a growing body of quasi law. But it would result in fewer rulings. On balance, the committee decided that the advantages of the rulings process (certainty for the taxpayer and intelligence

48 See further Sawyer "Binding Rulings in New Zealand - An Overview and Review of the First Ten Years", above $\mathrm{n} 31$.

49 Committee of Experts on Tax Compliance Tax Compliance: A Report to the Treasurer and Minister of Revenue, above $\mathrm{n} 5$.

50 At 284 (emphasis added). 
for the Commissioner) outweigh the advantages of publication. The committee therefore does not recommend a change.

Through the Committee, John was afforded the opportunity to evaluate the New Zealand binding rulings regime which (indirectly at least) draws upon John's seminal work. In particular, a feature which John suggested should be part of his proposed regime (deidentified or sanitised private rulings being published) would not be revisited in terms of a recommendation to the Government for change. Overall, the Committee's final statement on the binding rulings regime is concise and to the point: ${ }^{51}$

17.40 The committee endorses the current rulings process. It recommends that the issuing of product rulings should clearly be discretionary, as is already the case with public rulings. In exercising its discretion to issue public and product rulings the policy implications of such rulings should be taken into account.

One change recommended by the Committee is to clearly state that the issuing of product rulings is at the discretion of the Commissioner, in contrast with private rulings. The choice of words in the legislation, "to make" for private rulings, compared to "may make" for public, product, short process and status rulings, reflects this distinction.

The recommendation to take policy implications into account when the Commissioner is exercising her discretion potentially suggests wide consideration of factors beyond the facts and relevant laws is necessary, along with recognising constraints on Inland Revenue's resources. In an environment of transparency, one would hope that reasons are provided for why particular policy issues were taken into account when the Commissioner exercised her discretion. An example of this interaction with policy was highlighted by the Committee when it closely investigated the issuing of product rulings relating to passive investment funds. The Committee questioned the desirability of the situation, arising as a result of tax policy choices, that product rulings had shaped the way in which investment markets operated, potentially leading to suboptimal outcomes. The Committee did recognise, however, that this achieved the same result indirectly as would changes made to the tax legislation. ${ }^{52}$

Given the nature of the Committee's comments and recommendations, no significant amendments were recommended to the Government to be considered for refining the relevant legislation, although clearly Inland Revenue would need to reflect on the comments made. John's contributions in serving on the Committee is the last significant public contribution he has made to the subject of binding (advance) rulings in New Zealand. ${ }^{53}$ John has, however, published an article exploring certain public

51 At 290 (emphasis in italics added).

52 At 284-290.

53 John also made a further contribution to the New Zealand branch of the International Fiscal Association in 1999: see J Prebble Rulings and Avoidance (New Zealand Branch of International Fiscal Association, 1999). 
statements formerly known as "policy statements" and now called "interpretation guidelines". ${ }^{54}$ John clearly distinguishes these guidelines from other forms of opinions or statements, primarily binding rulings, determinations and standard practice statements. John suggested that: ${ }^{55}$

... the Commissioner should consider issuing interpretation guidelines very sparingly, if at all, in areas where the law depends primarily on an approach or method of reasoning, and where relevant facts vary infinitely from case to case.

I would add that the situation described by John is one where a binding ruling may be more appropriate or perhaps clarification of the underlying law itself should be undertaken through appropriate legislative amendment.

\section{REFLECTIONS ON RECENT DEVELOPMENTS}

\section{A Continuing to Reform the Binding Rulings Regime}

The binding (advance) rulings regime in New Zealand has undergone several reviews, the first being the administrative review in 1999 when minor changes were made to ensure the legislative system reflected Inland Revenue's administrative operation of the regime. This review accompanied the commencement of the process in 1998 leading to formalisation of the self-assessment system that was in place by the 2002-2003 income year. ${ }^{56}$ The origin of these changes is a detailed Legislative Review Report prepared by the Adjudication and Rulings Group (as it was then known) describing. ${ }^{57}$

... a large number of matters which have arisen as issues or difficulties since the 1 April 1995 commencement of the new regime. Some of these are mechanical issues, while others are matters of policy - some are blindingly obvious as to what needs to be done, but others raise quite complex questions about which the Rulings Unit does not necessarily have a concluded view.

54 J Prebble "Commissioner's Interpretation Guidelines: Some Consequences from Publishing Them" (2004) 19 Australian Tax Forum 243.

55 At 264

56 See Inland Revenue Legislating for Self-Assessment of Tax Liability - A Government Discussion Document (1998); and A Sawyer "What are the Lessons for Australia from New Zealand's First Comprehensive Remedial Review of its Binding Rulings Regime?", above n 31. Changes were made to s 92 of the Tax Administration Act 1994 such that a taxpayer who is required to file a return of income for a tax year must make an assessment of their taxable income and income tax liability and, if applicable for the tax year, the net loss, terminal tax or any refund due.

57 M Smith Commentary on the Binding Rulings Regime: A Practical Critique (ICANZ National Tax Conference, November 1996) at 6, as quoted in A Sawyer "Binding Rulings in New Zealand - An Overview and Review of the First Ten Years", above n 31 (emphasis added). This group later became known as the Taxpayer Rulings Unit which is part of the Office of the Chief Tax Counsel of Inland Revenue. It is now referred to as the Tax Council Office (TCO) business group of Inland Revenue, which provides technical advice about the interpretation and application of tax law to Inland Revenue and to its customers (taxpayers). 
As Sawyer observes, this Legislative Review Report was the outcome of a comprehensive internal review of the practical operation of the binding rulings system to identify areas where the legislation was not matching operational expectations. ${ }^{58}$ The Adjudication and Rulings Group (known now as the Tax Council Office) invited and considered suggestions from tax practitioners who had experience with some of those areas within the binding rulings regime.

This initial review process was followed by submissions on the ensuing draft legislation, which included an increase in the fees (by way of a change to the regulations) and introduction of the new type of ruling, known as a status ruling, through the Taxation (Accrual Rules and Other Remedial Matters) Act 1999. These developments occurred after the Committee reported in late 1998.

Well after the Committee had reported, further remedial changes were made with effect from October 2002 through the Taxation (Relief Refunds and Miscellaneous Provisions) Act 2002. These amendments enabled public rulings to be issued with an indefinite life (the aim being to reduce the work by rulings staff to revisit and reissue existing public rulings every three years), removed the requirement for notification to be in writing for product and status rulings and provided some minor (remedial) corrections. Since 2002, further remedial changes have been made to the statutory regime as and when necessary.

The most significant recent reform at the time of writing was introduced through the Taxation (Annual Rates for 2018-2019, Modernising Tax Administration, and Remedial Matters) Act 2019. This Act introduced a new process simplifying the requirements for applying for a binding ruling, as well as to allow Inland Revenue to reduce the fees for smaller entities and/or transactions. The key features are set out in ss 91EK to 91ET of the Tax Administration Act 1994. In summary, this new feature (referred to as short process rulings) provides:

- that a person with annual gross income below the prescribed level (set currently at $\$ 20,000,000)$ and a tax question involving tax below the prescribed level (set currently at $\$ 1,000,000)$ can apply for an abbreviated ruling;

- for removal of the requirements in applying for a binding ruling to state the taxation laws and the propositions of law for which the ruling is sought; and

- the application and hourly rate fees for private binding rulings will be lower for short process rulings at rates determined and published by the Commissioner.

In order for a taxpayer to make an application, it needs to be made in a form prescribed by the Commissioner and must:

- $\quad$ identify the person applying for the ruling;

- describe the circumstances on which the ruling is sought;

58 A Sawyer "Binding Rulings in New Zealand - An Overview and Review of the First Ten Years", above n 31. 
- disclose all relevant facts and documents; and

- state the general tax outcome in relation to which the ruling is sought.

These requirements are much simpler than those currently required in ruling applications as they do not, for example, require the applicant to set out the taxation laws and the propositions of law for which the ruling is sought. Behind this change is the aim to open up the binding rulings regime to a wider range of taxpayers, including more small and medium-sized enterprises (SMEs). This additional facility should assist in overcoming a major concern with the regime that it is only really available to large taxpayers with significant available funding (and access to tax specialists). This was also a concern that John had recognised in his seminal work in the 1980s and while serving on the Committee..$^{59}$ The extension to the ambit of the binding rulings regime to incorporate short process rulings will require additional resourcing from Inland Revenue. As at the time of writing, it is too early to assess the effectiveness of this new short process ruling facility.

A further amendment was made with the Taxation (KiwiSaver, Student Loans, and Remedial Matters) Act 2020 to clarify that where the Commissioner has issued a private, short-process or product ruling for an issue that does not involve an arrangement, and the ruling is withdrawn, taxpayers can continue to apply the ruling for the period specified in the ruling. The application date for this change with respect to private and product rulings is from 18 March 2019 and for short-process rulings it is from 1 October 2019.

In its 2020 Annual Report released in early 2021, Inland Revenue comments: ${ }^{60}$

Taxpayer rulings give Inland Revenue's interpretation of how the law applies in specific circumstances. This year, we ruled on $\$ 11.9$ billion worth of arrangements, where the associated tax at issue was more than $\$ 1.18$ billion.

Significant transactions ruled on included company group restructures, insurance and the new base erosion and profit shifting provisions, which concern tax avoidance strategies exploiting gaps and mismatches in tax rules to minimise tax.

Previously, in its 2019 Annual Report released in September 2019, Inland Revenue comments: ${ }^{61}$

The demand for rulings was still high this year, with significant transactions ruled on involving insurance, infrastructure and housing. A larger proportion of our applications than usual concerned GST and we have started to receive requests for rulings on the new base erosion and profit shifting provisions.

59 Prebble Advance Rulings on Tax Liability, above n 9.

60 Inland Revenue Annual Report (2020), above n 47, at 42 (emphasis added).

61 Inland Revenue Annual Report (2019) at 46. 
In 2018-19, 100\% of customers who returned surveys were very satisfied with our rulings service, with customers generally very happy with the timing and the quality of our work.

Similarly, in its Annual Report for 2018, Inland Revenue comments: ${ }^{62}$

This year we ruled on $\$ 54$ billion worth of arrangements, where the associated tax at issue was more than $\$ 16$ billion. Last year we ruled on $\$ 13.4$ billion worth of arrangements, where the associated tax at issue was more than $\$ 2.4$ billion.

Overall, $88 \%$ of customers were very satisfied with our rulings service this year, with the remaining $12 \%$ satisfied. Our survey responses showed customers were generally very happy with the service we are providing, in terms of both the timing and quality of our work.

In its Annual Report for 2017, Inland Revenue commented that 89 per cent of its "customers" were very satisfied with its rulings service, with the remaining 11 per cent satisfied, a similar result to $2018 .{ }^{63}$ Clearly Inland Revenue's rulings service is appreciated by its "customers" ("customer" is a term John does not support in the context of taxpayers engaging with Inland Revenue in regard to their tax liabilities and obligations). ${ }^{64}$

The breadth of areas for which taxpayers seek certainty is expanding into even more complex areas such as the OECD's base erosion and profit shifting (BEPS) developments, reflected in recent binding ruling applications. ${ }^{65}$ Globally, an expansion of the rulings system is the exchange of rulings as part of the OECD's BEPS Action Plan. Under Action 5 (a minimum standard), jurisdictions must engage in the compulsory spontaneous exchange of relevant information on taxpayer-specific rulings which, in the absence of such information exchange, could give rise to BEPS concerns. ${ }^{66} \mathrm{New}$ Zealand is actively involved in this process, successfully completing its first exchange of information of rulings in the 2017 financial year. In its Annual Report for 2018, Inland Revenue comments: ${ }^{67}$

62 Inland Revenue Annual Report (2018) at 50 (emphasis added).

63 Inland Revenue Annual Report (2017) at 38.

64 For a discussion on the inappropriateness of using "customer" see J Prebble "Customers, Branding, and Mottoes in the New Zealand Inland Revenue Department" in Michael Walpole and Chris Evans (eds) Tax Administration in the 21st Century (Prospect Media Pty Ltd, St Leonards NSW, 2001) at chapter 7.

65 For further details on BEPS, see the OECD's website at: 〈www.oecd.org>. As the OECD indicates, each of the four BEPS minimum standards is subject to peer review in order to ensure timely and accurate implementation. It is also intended to safeguard the level playing field. All members of the OECD's Inclusive Framework on BEPS have committed to implementing the Action 5 minimum standard and committed to participating in the peer review.

66 OECD Action 5 Harmful Tax Practices (2015).

67 Inland Revenue, above n 63, at 59. 


\section{Exchange of Tax Rulings}

We successfully exchange tax rulings with our treaty partners. We are participating in facilitating international tax transparency and reducing the opportunities for harmful tax practices.

\section{B Other Areas of Advice/Interpretation from Inland Revenue}

In addition to the binding (advance) rulings regime, the Commissioner continues to provide a wide range of advice and interpretations of the law. These include:

- Determinations under Part 5 of the Tax Administration Act 1994, which are usually on specific areas of the law that are complex. They cover areas such as livestock, depreciation rates and foreign source income amounts. These are binding on the Commissioner and to taxpayers where applicable.

- Non-binding rulings/advice: A request for an indicative view of the Commissioner forms the basis of non-binding rulings/advice. These statements are not binding on the Commissioner and cannot be relied on by taxpayers such that the Commissioner may change her view at a later time. As noted earlier, there is no scope for arguments of estoppel or legitimate expectations in New Zealand to be established against the Commissioner.

- $\quad$ "Questions We've Been Asked" (QWBA): Taxpayers may ask Inland Revenue for a response to a query they have. Inland Revenue may determine to provide an answer (which is not binding) to the query and publish it (anonymously) as a QWBA, usually in the Tax Information Bulletins.

- Interpretation statements $(I S)$ and interpretation guidelines $(I G)$ that set out the way Inland Revenue/Commissioner has interpreted the law in particular instances or on areas in which the law may be considered to be unclear (which are not binding).

- Operating statements (OS) and standard practising statements (SPS), which are guidance on Inland Revenue's administrative practices, assisting both Inland Revenue staff in performing their duties and providing information for taxpayers about what they can expect in terms of their dealings with Inland Revenue. While not binding on the Commissioner, these statements are made publicly available to assist taxpayers with understanding how Inland Revenue will apply areas of law in practice.

In the above list, the only form of advice or interpretation that is binding on the Commissioner is a determination issued under pt 5 of the Tax Administration Act 1994. All other forms of advice and interpretation are at best indicative and informative, but should not be relied upon, and cannot be challenged through arguments based on estoppel, legitimate expectations or through judicial review. This distinction is important and justifiable given that binding rulings and determinations are legislatively provided mechanisms that enable the Commissioner to provide binding advice and interpretation. That said, binding rulings and determinations remain subject to Parliament changing the law and to the courts interpreting the law in another manner than that applied by the Commissioner. When this occurs, the binding ruling or determination remains in effect for the remainder of its period 
of application in the latter situation, but will cease to apply from the date that the law change enacted by Parliament takes effect.

As part of the consultation process, before a public ruling or a determination is issued, a draft public version reflecting Inland Revenue's preliminary views on the relevant topic is circulated for public comment. Unsurprisingly, these draft public rulings and draft determinations are not binding on the Commissioner. Submissions made on these drafts are considered by the Taxpayer Rulings Unit prior to finalisation of the public ruling or determination. This emphasises the need to ascertain that a ruling or determination is the final issued version, along with a close examination of the period of application, details of the arrangement and, where applicable, the persons that may rely on the ruling. Inland Revenue's website provides further details including an overview of the rulings system that operates currently in New Zealand. ${ }^{68}$

\section{CONCLUDING OBSERVATIONS}

At this point I would like to tentatively reflect on how John might remark on the current state of binding rulings in New Zealand with respect to his earlier vision in the mid-1980s. It should go without saying that John would fully support having such a regime in place, especially one that provides high-quality output that meets the expectations of applicants, particularly with respect to providing greater certainty for their tax obligations and liabilities. There would be, I might suggest, some quibbles from John concerning some aspects that do not align with his original vision in his seminal work, including potentially whether there should be appeals/challenges and a sanitised form of publication of private rulings. ${ }^{69}$ That said, the Committee of which John was a member, largely endorsed the regime as it operated in $1998 .^{70}$ There is no evidence of whether this was a consensus view or one where concessions were made by one or more members. The Committee's endorsement of the regime included the original policy decision not to publish private rulings, not to include any form of appeal mechanism for applicants and to utilise a fee charging mechanism (full cost recovery). Nevertheless, the legislated regime is much more extensive than John's original vision (including his draft code for a binding (advance) rulings regime) with additional features including product rulings and later on status rulings, along with much more complex statements on the limitations of scope to rule, discretions and the like. ${ }^{71}$

Given the costly nature of applying and receiving a binding ruling (including the substantial costs of engaging a tax adviser and Inland Revenue's costs that are on-charged), the short process rulings

68 See Inland Revenue "What is a binding ruling" Tax Technical <www.taxtechnical.ird.govt.nz〉.

69 Prebble Advance Rulings on Tax Liability, above n 9.

70 Committee of Experts on Tax Compliance Tax Compliance: A Report to the Treasurer and Minister of Revenue, above n 5.

71 Prebble "Advance rulings: a proposed procedure", above n 20. 
facility should open up the binding rulings regimes to more applicants, including more SMEs. This should improve the degree of certainty that is highly sought after by businesses, a feature that John highlighted in his contributions to the literature on binding (advance) rulings. ${ }^{72}$ Given the very recent timing of this new facility, no conclusions as to whether it is meeting taxpayer needs can be made.

John's foresight for a binding (advance) rulings system took some time to come to fruition, with his seminal work published in 1986, and the Government decision to develop a regime not announced until 1992 (and given legislative effect from 1 April 1995). This is not an uncommon experience for academics who may put forward well-crafted proposals that do not see any tangible application, if at all, for many years. "Blue skies" or "pure" research, which is typically seen as the domain of those in the sciences, may not have an immediate commercial application but is aimed at increasing our scientific knowledge. Academics in the tax discipline typically do not typically engage in this type of research, and therefore, contributions from academics of this nature take greater importance. ${ }^{73}$ More typical research from academics involves undertaking research to (re)solve an existing problem or issue ("applied research"). This type of research is also where consultants may be engaged in relation to a specific task, often to provide detailed analysis and recommendations to support a current policy proposal. Several of John's contributions to the binding rulings regime take the form of blue skies research (his seminal work, for example) $)^{74}$ as well as a form of consultancy through his membership of the Committee. ${ }^{75}$

My curiosity surrounding the Commissioner's advice and rulings commenced several years before the regime was enacted which coincidentally was when I commenced my academic career in 1991. My interest was inspired not only by the growing concerns over the limitations of the non-binding forms of advice and rulings taxpayers could receive from Inland Revenue, but more importantly through reading John's early works, including his seminal work. ${ }^{76}$ Not only did John's inspiration lead me to undertaking several academic reviews of New Zealand's regime that were subsequently published, but this also facilitated a consultancy engagement with Inland Revenue to undertake an international comparative review of (binding) rulings regimes. ${ }^{77}$

72 See for example, Prebble Advance Rulings on Tax Liability, above n 9.

73 I have argued elsewhere that tax is an emerging discipline. See A Sawyer "Who cares about Tax Theory, and Why?: The Place of Tax Disciplines within Academia - A Comment" (2018) 24(3) New Zealand Journal of Taxation Law and Policy 221.

74 Prebble Advance Rulings on Tax Liability, above n 9.

75 Committee of Experts on Tax Compliance Tax Compliance: A Report to the Treasurer and Minister of Revenue, above $\mathrm{n} 5$.

76 Prebble Advance Rulings on Tax Liability, above n 9.

77 See generally, above n 31, especially A Sawyer "Comparing New Zealand's Private Rulings System and its Features with a Selection of International Private Rulings Systems - What is There in Common?" (2002) 5(3) 
Outside of John's work on binding rulings, his extensive breadth and depth of research in tax jurisprudence generally have provided the impetus for a significant amount of my research outside of binding rulings, including areas such as tax avoidance. John's publications also serve as excellent reference material for my students. There is no doubt in my view that John's scholarship is of the highest quality, although personally I find aspects (such as ectopia and autopoiesis) very challenging to fully appreciate. This is not an indictment on John's work but on my own intellectual capacity to engage in these areas further.

In retirement I would sincerely hope that John will continue to make academic contributions to tax jurisprudence, including binding rulings. Leading scholars and figures in the law in a sense do not necessarily "retire" but hopefully find some time free of other "constraints" to reflect further on the areas of their expertise. They may even find time to become involved in groups and organisations that depend upon their expertise, passion and experience to succeed. I do hope to see John's contributions continue and will follow them with interest.

Journal of Australian Taxation 440; and A Sawyer "Binding Rulings: A Comparative Perspective" in Andrew Lymer and John Hasseldine (eds) The International Taxation System (Kluwer, Amsterdam, 2002) at 291-315. 